
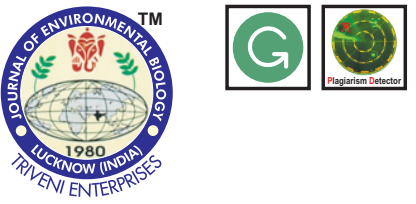

DOI : http://doi.org/10.22438/jeb/38/5(SI)/GM-35

\section{Journal of Environmental Biology}

ISSN: 0254-8704 (Print) ISSN: 2394-0379 (Online) CODEN: JEBIDP

\title{
Determination of landscape hydrological resources- methodological aspects: A case study from Georgia
}

\section{Authors Info}

D. Nikolashvili', V. Trapaidze', D. Svanadze ${ }^{1}$ and M. Tsitsagi ${ }^{1,2 *}$ ${ }^{1}$ Department of Geography, Faculty of Exact and Natural Sciences, Ivane Javakhishvili Tbilisi State University, Tbilisi, 0179, Georgia

${ }^{2}$ Department of Geomorphology and Geoecology, Vakhushti Bagrationi Institute of Geography, Ivane Javakhisvili Tbilisi State University, Tbilisi, 0179, Georgia

*Corresponding Author Email : mariam.tsitsagi@tsu.ge

Key words

Georgia,

GIS,

Landscape studies,

Water resources

\section{Publication Info}

Paper received : 15.11.2016

Revised received : 25.06.2017

Accepted : 27.06.2017

\section{Abstract}

Aim: The aim of this paper is to determine quantity of the water resources according to the landscapes in Georgia, using multifactorial analysis.

Methodology: Assessment of water resources (hydro resources) potential of landscapes requires multifactorial analysis. Their potential is determined by quantity of influent and effluent waters during certain time periods. This study was mainly based on multiyear hydrological data of Georgia covering 90 rivers. Series of observations included a time scale of 40-50-years and in some cases even 70-years. Study was based on cadastral data of 150 hydrological stations/posts.

Results: We investigated different and similar landscapes according to total supply of water resources. The landscapes situated under more or less uniform physico-geographical conditions are similar in their total supply of water resources. Landscapes within the limits of one type or even subtype differ according to the supply of water resources, particularly water resources supply is maximal under these conditions.

Interpretation: Accuracy of our results has been testified by the circumstances. We got approximately the same total values for whole Georgia as determined by the calculations made by different scientists using differentmethods.
Determination

of water resources quantity

according to landscapes

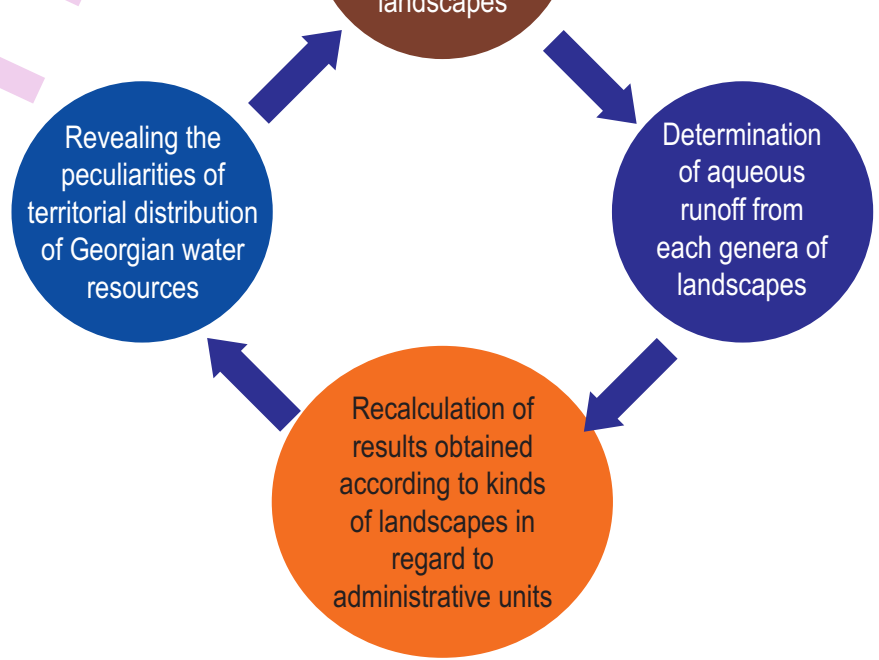




\section{Introduction}

Assessment of natural resource potential is one of the key issues in scientific research disciplines. Many attempts have been made on the determination of natural resource potential, but the published data where this issue has been considered in the landscape context is very scarce. Natural resource potential of landscapes can be assessed in different contexts, in particular from climatic, hydrological, scientific and other viewpoints. Among these, the assessment and analysis of water resources is one of the most important issues. It gives us an opportunity to enlighten not only resource potential of landscapes, but also determine the physical and geographical tendencies taking place in this context.

Water resources assessment, including water balance determination is complex and labor-consuming process, which should be based on multifactorial analysis. A water balance equation to be generated for this purpose. In this study, we are elaborating the determination of method of water resources potential using landscape approach. The assessment according to the regions, countries and administrative-territorial units is of frequent occurrence in different research studies, but the assessment from the viewpoint of "natural boundaries" is significantly lacking.

The processes common to some or all landscapes can be distinguished from the processes unique to particular landscapes only by evaluating landscapes from a common conceptual hydrological framework (Wolock et al., 2004). According to this "Hydrological-Landscape Concept" a single physical feature is the basic building block of all landscapes (Winter, 2001).

It is important to carry out assessment of water resources of one or more territories on the basis of landscape approach. This will give us an opportunity to determine the situation of water resources "within natural boundaries". Based on practical needs and with the purposes of more accuracy it is very important to determine water resources potential according to landscapes and only afterwards to "recalculate" it according to administrativeterritorial units. This kind of research will give us an opportunity to assess more really and with more accuracy water resources of one or more than one administrative-territorial units, and it becomes precondition of rational and effective management of natural resources. An elaboration of the studies on the determination of method for landscape water runoff is an important aspect. Much work has been undertaken to elaborate the equation of water resources, including water balance (Khomeriki and Alaverdashvili, 2003). However, the studies related to the water resources on the basis of background of landscapes is especially very scarce, in particular in the cases where landscape-hydrological zoning is made on the basis of territory of a country (Kavrishvili, 1955). It is noteworthy, that in some published data concerning separate types of landscapes, complicated interrelation existing between the environmental conditions and hydrological objects have been considered. For instance, for determining the vulnerability of semi-arid landscapes within the concept of natural and human-induced landscape pattern changes linkages between hydrological modelling and landscape assessment tools has been developed (Hernandez et al., 2003; Nemykin,2005;Fedorov,2007). In some studies the regularities of water balance have been established, which are preconditioned by landscape factors of different regions on global scale (Fedorovsky, 1984; Gagarinova, 2012; Trifonova et al., 2009).

Similar investigations have been carried out on the water resources of Caucasus including Georgia. But, in this area much more work has been done on the determination of water resources within political and administrative boundaries. One of the important exceptions may be the study where the landscapehydrological zoning has been given (Vladimirov et al., 1974; Khmaladze, 2009; Basilashvili et al., 2015).

Tremendous number of papers have been published covering quantitative characteristics of water resources of the whole territory of Georgia, in particular "Georgian water balance" (Khmaladze, 2009; Vladimirov et al., 1974). These studies describe and analyse the water discharge of main rivers of Georgia, with a significant place allotted to the studies related to an assessment of hydropower resources (Svanidze and Tsomaia, 1988). A part of these studies are devoted to the determination method of separate hydrological characteristics (Kereselidze et al., 2009), as well as hydrological zoning of Georgian territory and climate change features, together with the quantitative characteristics of water (Kereselidze et al., 2012). Very important information is available in the yearbook of quantitative characteristics of Georgian water resources, which has been published by hydrometerological service (State Water Cadastre, 1967, 1977, 1987, 1978).

\section{Materials and Methods}

Georgia is highly rich in water resources and possesses a total capacity of around $106 \mathrm{~km}^{3}$ (Khmaladze, 2009). The biggest capacity i.e., more than $97 \%$ is concentrated in rivers $\left(61 \mathrm{~km}^{3}\right)$, glaciers $\left(24 \mathrm{~km}^{3}\right)$ and swamps. The rivers belong to the bins of Black Sea (Atlantic Ocean) and Caspian Sea. There is a big nonuniformity in water resources distribution. Western Georgia is especially rich as compared to the Eastern part. In fact $80 \%$ of the total national water resources supply is present within the borders of Western Georgia and these are distinguished by frequency of river networks (Khmaladze, 2009). They are nourished by rain and swamp waters.

The river network of Eastern Georgia completely belongs to the Mtkvari river basin $\left(21.120 \mathrm{~km}^{2}\right.$ in area), which is the most water-abundant (runoff volume is $6500 \mathrm{~km}^{3}$, and water catchment area is $12000 \mathrm{~km}^{2}$ ) (Khmaladze, 2009). Rivers of the Northern Georgia belong to the basins of Tergi River. Area of territory occupied by these is only $4 \%$ of country area. 
An assessment of the hydro resources potential of landscapes requires multifactorial analysis. Concept of landscape spatiotemporal analysis and synthesis (Beruchashvili, 1983) on one hand, and water balance determination, on the other hand are used as a methodological basis of research. Core value of the concept of landscape spatiotemporal analysis and synthesis is an opportunity for identification of natural components, their dynamics and current state of landscapes using united methodology. The use of this methodology can determine natural-resource, including hydrological potential with very high accuracy. The potential is determined by quantity of influent and effluent waters during certain time period.

We have tried to determine water quantity for closed section of river basin that gave us an opportunity to take into account anthropogenic changes of balance elements, to determine unknown elements by means of other known elements, to identify water resources of insufficiently investigated territories, and to assess representativeness of observed data. This study was mainly based on multiyear cadastral hydrological data of Georgia. There are long-period observations (water levels and discharge) for roughly 90 Georgian rivers. Series of observations include 40-50-years data and in some cases even over a period of 70 -years.

The basis of this study was collection of cadastral data of 150 hydrological stations/posts (State Water Cadastre, principal hydrolgical properties, 1967, 1978, 1987). This gave us an opportunity to establish and assess water resources of Georgian landscapes with quite high accuracy. The country is quite well equipped with hydrological stations/posts which is confirmed by the fact that at least 1 observation point is situated in the majority of landscapes, except for some exceptions like; high mountain alpine areas, sub-nival and glacial-nival spots, as well as less densely populated landscapes of dry regions of Eastern Georgia. Relatively different situation is met within the mountains, where total amount of hydrological stations/posts equals to 150. Majority of these are located in the plains and foothill landscapes and the mountainous landscapes are least provided.

The number of hydrological stations/posts has sharply come down to 20 units lately (Fig. 1) (Chitanava, 2009), and this is reflected in the data accuracy. The data available is sufficient for their consideration as representative examples and for determination of peculiarities of water resources territorial distribution with high accuracy.

In this study we have used different types of information such as: annual meteorological data of hydro-meteorological department of Georgia; climate data reference books made by Environmental Agency of Georgia; archival data of $L A B$ for Studying Environmental Conditions by Space Methods of Tbilisi State University (up to 1992), and others. All these are scattered over different scientific sources. Our study included the following stages (Fig. 2);

First stage was related to the matching of hydrological stations/posts with landscapes based on the procedure of map overlay of Georgian landscape map (Beruchashvili, Landscape Map of Caucasus. 1:1,000,000.) and hydrostation layers. 91 river basins were selected on the territory of Georgia and these were divided according to the landscapes (71 parcels). We obtained a vast database through GIS', with 9342 records.

Second stage was related to the determination of water runoff for each landscape parcel based on GIS procedures and

Number of hydrological stations

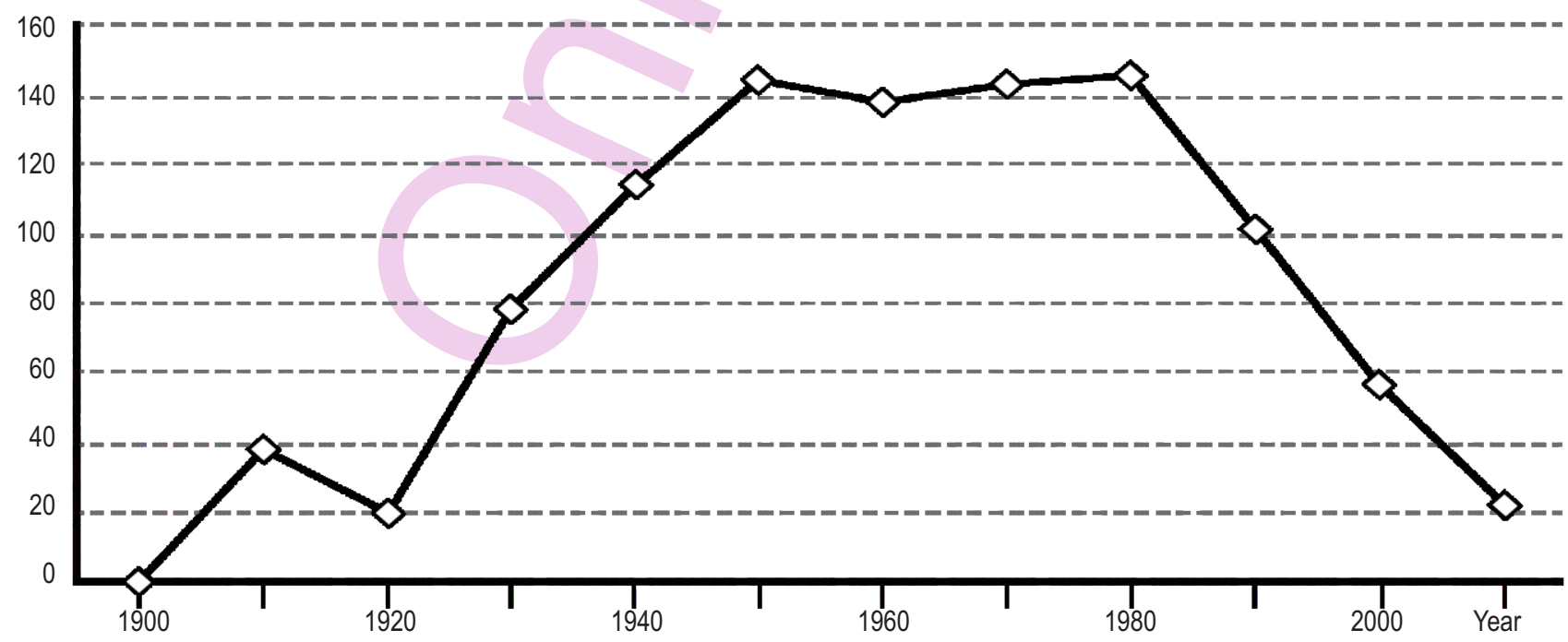

Fig. 1: Dynamics of hydrological observations in Georgia, 1900-2010 
numerous statistical calculations, conducted in the following sequence: study area was divided into 150 river basins; the runoff module, i.e. the quantity of water, which flows away from $1 \mathrm{~km}^{2}$ of basin area within 1 second was determined on the basis of basin area located above closed section.

These calculations, including big rivers, were made with high accuracy, because we have the data of extremely accurate observations for the whole territory of Georgia. For the territory lacking information, we used the method of analogies, extrapolation and interpolation - on the basis of data of adjacent basins with similar physico-geographical characteristics.

The following calculations were made: a) average river discharge for multi-year period $\left(\mathrm{m}^{3} / \mathrm{sec}\right)$; b) values obtained were divided into basin area and runoff module, i.e. quantity of water flowing from $1 \mathrm{~km}^{2}$ within 1 second was determined; c) river basins were divided according to contours of landscape parcels and runoff module, quantity of water flowing within 1 second $\left(\mathrm{m}^{3}\right)$ and annually $\left(\mathrm{km}^{3}\right)$, was determined for each of these landscapes.

On the basis of these calculations it was possible to determine the quantity of water, which annually flows within each of the landscape parcels on average basis. Summarized data of runoff module was calculated according to the types, subtypes and classes of landscapes:
In the third stage of research - recalculation of results obtained was carried out according to the landscape parcels and regarding the administrative units the calculations were reconducted on landscape basis. Thus, landscape parcels were cut according to the contours of administrative units (regions) and runoff module was determined on the basis of each of these units. Fourth stage of research included identifying the peculiarities of territorial distribution of Georgian water resources.

\section{Results and Discussions}

The analysis of runoff module according to separate landscapes showed us (Table 1) that its maximum volume $\left(19,158 \mathrm{~m}^{3} / \mathrm{s}\right.$ per $\left.1 \mathrm{~km}^{2}\right)$ falls on middle mountain forest landscape and equals to almost one third of total runoff of Georgian waters (Fig. 1). In these landscapes exactly an accumulation of the biggest supply of Georgian phytoresources is observed, including a maximum value in the middle mountain forest landscapes of Western Georgia with an abundance of beech and dark coniferous forests and it equals to $400-500 \mathrm{t} \mathrm{ha}^{-1}$ on an average basis (Beruchashvili, 1995; Nikolaishvili, 2009; Tediashvili, 1984).

Most of the big rivers of Western Georgia spring from Caucasus Mountains where majority of glaciers are accumulated

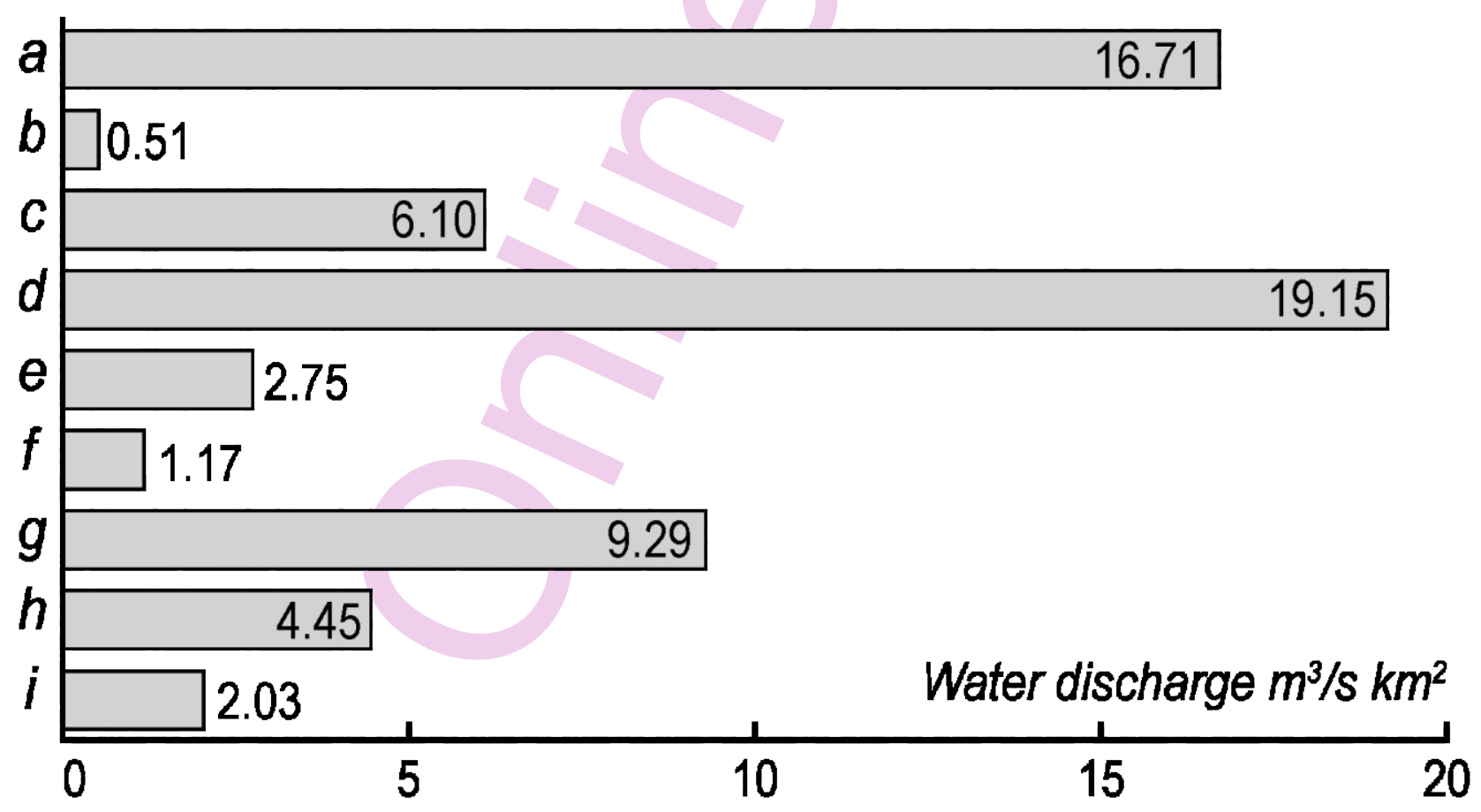

(a) Plain; (b) Low mountain with open woodlands, steppes; (c) Low mountain forest; (d) Middle mountain forest; (e) Upper mountain forest; (f) High plateau with steppe; (g) High mountain subalpine; (h) High mountain alpine; (i) High mountain subnival and nival

Fig. 2 : Distribution of water discharge on the basis of landscapes in Georgia 
Table 1 : Basic results of water b.alance calculation of Georgian landscapes

\begin{tabular}{|c|c|c|c|c|c|}
\hline $\begin{array}{l}\text { Landscape classes } \\
\text { and types }\end{array}$ & Landscape subtypes & No. & Area & $\begin{array}{l}\text { Runoffs, } \\
\mathrm{km}^{3}\end{array}$ & $\begin{array}{l}\text { Per km³ }{ }^{3} \\
\text { thous. } \mathrm{km}^{2}\end{array}$ \\
\hline \multicolumn{6}{|c|}{ Plain and hilly landscapes } \\
\hline Subtropical, humid & Kolkhetian, forest $(1-10)$ & 1 & 9.64 & 12.670 & 15.548 \\
\hline \multirow{2}{*}{$\begin{array}{l}\text { Sub-Mediterranean } \\
\text { semihumid }\end{array}$} & Transient to Kolkhetian, forest (13-14) & 2 & 0.07 & 0.132 & 3.324 \\
\hline & $\begin{array}{l}\text { Transient to moderately heated, semihumid, forest and } \\
\text { dry shrubs(18-21) }\end{array}$ & 3 & 2.51 & 0.88 & 1.337 \\
\hline Subtropical semiarid & Steppe, dry shrubs and semi desert(22-26)- & 4 & 2.24 & 1.251 & 1.859 \\
\hline Subtropical arid & Desertand semidesert(29) & 5 & 0.09 & 0.010 & 0.107 \\
\hline Moderately heated arid & Transient to subtropical, forest (30-31) & 6 & 1.27 & 1.152 & 1.788 \\
\hline \multirow{2}{*}{$\begin{array}{l}\text { Hydromorphous and } \\
\text { sub-hydromorphous }\end{array}$} & Swampy, meadow and tugai $(48 ; 51)$ & 7 & 1.74 & 0.622 & 2.457 \\
\hline & Plain landscapes & 17.56 & 16.717 & 26.42 & \\
\hline \multicolumn{6}{|l|}{ Mountain } \\
\hline Subtropical semiarid & Steppe, dry shrubs and arid-light forest (58-59) & 8 & 2.31 & 0.513 & 0.498 \\
\hline Subtropical arid & Desert and semidesert(61) & 9 & 0.05 & 0.0005 & 0.009 \\
\hline \multirow[t]{3}{*}{ Lower mountain-forest } & Kolkhetian $(62-66)$ & 10 & 4.05 & 4.383 & 4.811 \\
\hline & Kakhetian, of Greater Caucasus (75) & 11 & 0.81 & 0.399 & 0.492 \\
\hline & Transient to semihumid (79-83) & 12 & 3.28 & 1.319 & 1.731 \\
\hline \multirow[t]{2}{*}{ Middle mountain-forest } & Kolkhetian (68-72) & 13 & 6.31 & 7.933 & 7.017 \\
\hline & of Eastern Georgia (84; 88-89) & 14 & 4.91 & 3.278 & 2.351 \\
\hline \multirow[t]{3}{*}{ Mountain semiarid } & Transient to moderately heated, mountain-hollow, & & & & \\
\hline & meadow-steppe, dry shrubs and dry shrubs (102) & 16 & 0.38 & 0.081 & 0.428 \\
\hline & $\begin{array}{l}\text { High plateaus with steppe and meadow-steppe vegetation } \\
(112 ; 119)\end{array}$ & 17 & 1.22 & 1.097 & 1.131 \\
\hline \multirow{2}{*}{$\begin{array}{l}\text { Mountain moderately } \\
\text { cold }\end{array}$} & Middle mountain dark coniferous forest(125-127) & 18 & 5.02 & 7.947 & 4.047 \\
\hline & High mountain forest piny and birchen (129-134) & 19 & 4.71 & 2.750 & 3.028 \\
\hline \multirow[t]{3}{*}{ Mountain meadow } & Subalpine forest-shrubby-meadow (135-144) & 20 & 10.78 & 11.965 & 8.405 \\
\hline & Alpine shrubby-meadow (145-149) & 21 & 3.92 & 1.781 & 7.864 \\
\hline & High mountain subnival (150-151) & 22 & 0.49 & 1.498 & 6.669 \\
\hline \multirow[t]{3}{*}{ Glacial-nival } & Glaciers and rocks (152) & 23 & 3.47 & 0.536 & 0.150 \\
\hline & Mountain landscapes & & 51.71 & 45.481 & 48.631 \\
\hline & Sum & & 69.71 & 62.198 & 75.051 \\
\hline
\end{tabular}

Table 2: Water drainage according to the plain and mountainous landscapes of Georgia

\begin{tabular}{|c|c|c|c|c|c|c|c|c|c|}
\hline \multirow[t]{2}{*}{ Degree of Drainage Volume } & \multicolumn{3}{|c|}{ Number of Landscape Genera } & \multicolumn{3}{|c|}{ Area, thousand km² } & \multicolumn{3}{|c|}{ Water Drainage, $\mathrm{km}^{3}$} \\
\hline & Plain & Mountain & Total & Plain & Mountain & Total & Plain & Mountain & Total \\
\hline Very high & 1 & 3 & 4 & 2.660 & 11.534 & 14.194 & 3.405 & 14.293 & 17.698 \\
\hline High & 4 & 10 & 14 & 4.860 & 15.970 & 20.830 & 7.146 & 16.450 & 23.596 \\
\hline Moderate & 4 & 14 & 18 & 3.350 & 15.624 & 18.974 & 3.041 & 9.854 & 12.895 \\
\hline Low & 4 & 7 & 11 & 3.290 & 4.732 & 8.022 & 1.609 & 2.151 & 3.760 \\
\hline Very Low & 12 & 13 & 25 & 3.070 & 7.011 & 10.081 & 1.852 & 1.737 & 3.589 \\
\hline Total & 25 & 37 & 72 & 19.429 & 50.271 & 69.700 & 15.123 & 47.075 & 62.198 \\
\hline
\end{tabular}

(Gobejishvili, 1989). This fact preconditions better water supply of rivers of Western Georgia.

The valley landscapes are also distinguished by water runoff, but the biggest part (almost 78\%) again lies within Western Georgia. This fact obviously reflects a more non-uniform moistening of valley landscapes of Western and Eastern Georgia. Valleys of Western Georgia are represented by humid and partly extra humid landscapes, while valleys of Eastern Georgia are represented by semi-humid and partly arid and humid landscapes.

Coefficient of river network frequency clearly depicts a non-uniform distribution of water resources within Georgian territory. For the whole of Georgia this coefficient equals $0.78 \mathrm{~km}$ $\mathrm{km}^{-2}$ on an average. For Western Georgia the values are $1.07 \mathrm{~km}$ 


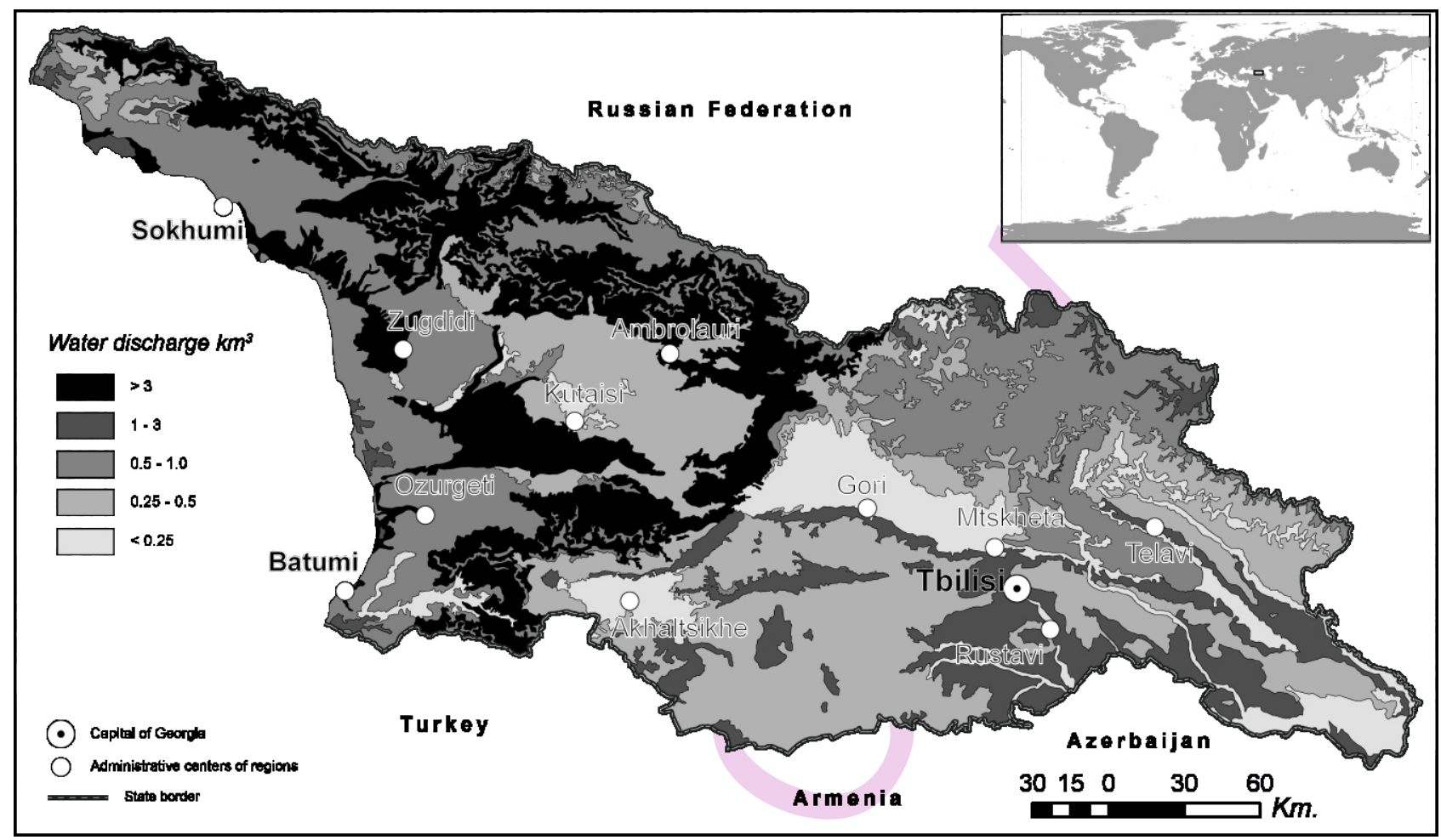

Fig. 3: Water Drainage of Landscapes of Georgia

$\mathrm{km}^{-2}$ and for Eastern Georgia it is only $0.68 \mathrm{~km} \mathrm{~km}^{-2}$. This index is especially high in Black Sea south coastal band $\left(2.5 \mathrm{~km} \mathrm{~km}^{-2}\right)$, while in outermost south-eastern part of Georgia it lies around $0.35 \mathrm{~km} \mathrm{~km}^{-2}$, being even lesser at some localities. If we take into account the circumstances on this territory, these are represented by the systems of irrigation channels, where this index is 3-times bigger compared to the natural one.

Even more informative is the index, which reflects the volume of water $\left(\mathrm{km}^{3}\right)$, annually flowing through each square unit $\left(\mathrm{km}^{2}\right)$ of our landscape. Middle mountain forest landscapes lead in this aspect on the basis of this index and exceed average national index $\left(91,078 \mathrm{~km}^{3} /\right.$ thou. $\left.\mathrm{km}^{2}\right)$ by almost 3.5 times. The valleys and high mountain subalpine landscapes are also characterized by the values larger than average index. Other abovementioned landscapes are however, characterized by an index lower than average national indicator.

As a main result of the research landscape parcels were divided into 5 categories on the basis of runoff volume (Fig. 2).

Landscapes with very high runoff $\left(>3 \mathrm{~km}^{3}\right)$. Only 4 parcels of the landscapes show this characteristic and all are represent in Western Georgia: middle mountain forest landscapes with abundance of beech forests, middle mountain forest landscapes with abundance of beech and dark coniferous forests, high mountain landscapes with subalpine meadows and the landscapes of Kolkheti valley-lowlands, which are found on its eastern periphery. Such high indices are preconditioned first of all by an abundance of atmospheric precipitation in Western Georgia. The index is especially high in middle mountain forest landscapes with prevalence of beech and dark coniferous forests and it is more than $6.2 \mathrm{~km}^{3}$. Despite the small quantity of classification units of landscapes, more than $20 \%$ of total national area and more than $25 \%$ of total runoff falls on these landscapes. As a result of these circumstances they fulfil important waterregulating function.

Landscapes with high runoff (1-3 $\left.\mathrm{m}^{3}\right)$. 4 landscape types, 7 subtypes and 14 parcels belong to these, and most are concentrated within forest boundaries. The biggest part of Kolkheti valley, low mountains landscapes and middle mountain forest landscapes of Western Georgia, fall in this category. In Eastern Georgia, only the middle mountain forest landscapes appear, which occupy large areas.

Landscapes with average runoff $\left(0.5-1 \mathrm{~m}^{3}\right)$. They include 8 types, 12 subtypes and 18 parcels of landscapes, occupying almost more than $1 / 4$ of national territory and almost $1 / 5$ of total runoffs. Significant part of landscapes include valleys and hills and hummocks of sub-mountain region of Eastern Georgia, as well as Javakheti plateau (Southern Georgia), which share the area. Water regulation in the most part of Javakheti plateau landscapes is dependent on the expense of lakes. The rivers are of reverse profile here.

Landscapes with small runoff $\left(0.25-0.5 \mathrm{~km}^{3}\right)$. They contain 8 
types, 10 subtypes and 11 parcels of landscapes. These landscapes are located both in Western and Eastern Georgia within the limits of mountains and lowlands. They are mostly the landscapes which are spread on small areas.

Landscapes with minimum runoff $\left(<0.25 \mathrm{~km}^{3}\right)$. Very big amount of landscapes are included in this category (25 landscape parcels). Majority are located in Eastern Georgia.

Results make sense because the large amounts of precipitations fall in western Georgia as a result of the movement of humid air masses from the Black Sea region (Javakhishvili, 1981). In particular, the annual flow all over the hypsometrical height in West Georgia is much more than in East Georgia. The annual distribution of precipitations is also different between eastern and West Georgia. South Georgia (Samtkhe-Javakheti) is also specific, with most of its territory characterized by cold, relatively dry winters, long cool summers and less amounts of atmospheric precipitations with an extremely uneven distribution both, in respect of time and area (Nikolaishvili, Sartania et al., 2016). All the above-listed factors result in the hydrological peculiarities and water content, kinds of alimentation and regime of the rivers.

After the runoff modelling different and similar landscapes were investigated according to total supply of water resources. The landscapes situated under more or less uniform physical geographical conditions are similar in their total supply of water resources. Landscapes within the limits of one type or even subtype differ according to the supply of water resources, particularly water resources supply is maximal under these conditions.

Thus, as a result of the research, the methods for calculate the annual water flow according to the landscapes were developed, and the resource potential of various landscapes of Georgia was evaluated and peculiarities of its territorial distribution were identified for the first time on its basis. Above mentioned method gives us an opportunity to determine the situation of water resources "within natural boundaries". Results are more accurate and the method becomes one of the main precondition of rational and effective management of natural resources.

\section{References}

Basilashvili, Ts., L. Matchavariani, L. Lagidze: Desertification Risk in Kakheti Region, East Georgia. J. Environ. Biol., 36, 33-37 (2015).

Beruchashvili, N.L.: Methodology of landscape-geophysical Researches of Conditions of Natural-territorial Complexes. Tbilisi, TSU (1983).

Beruchashvili, N. L.: Caucasus: Landscapes, Models, Experiments. Tbilisi: UNEP-Grid Arendal (1995).

Beruchashvili, N.L.: Landscape Map of Caucasus. 1:1,000,000. TSU, Tbilisi (1979).

Chitanava, R.: Hydrometeorological activity of Georgia. Regional Seminar (2009).
Fedorov, V.N.: Landscape Indication of River Runoff Formation. Irkutsk: Institute of Geography of Academy of Science (2007).

Fedorovsky, A.S.: Regularities of water balance formation for landscapes of the south of the far east. Moscow: Thesis of Candidate of Technical Sciences (1984).

Gagarinova, O.V.: Landscape-hydrological regularities of runoff formation in the baikal lake basin. Geogr. Nat. Reso., 3, 55-60. (2012).

Gobejishvili, R.: Glaciers of Georgia. Tbilisi: TSU (1989).

Hernandez, M., W.G. Kepner, D.J. Semmens, D.W. Ebert, D.C. Goodrich and S.N. Miller: Integrating a Landscape/Hydroloc Analysis for Watershed Assessment. The First Inteagency Conference on Research in the Watersheds, 27-30 October. Benson, AZ. (2003).

Javakhishvili, S.: Atmospheric precipitations on the territory of Georgia. Tbilisi. (1981)

Kavrishvili, V.I.: Landscape-Hydrological Zones of Georgian SSR. Tbilisi: TSU (1955).

Kereselidze, D., K. Bilashvili, V. Trapaidze and G. Bregvadze: Hydrological zoning of the territory of georgia and estimation of water resources on the background of the climate change. Proccedings of the 12th International Multidisciplinary Scientific Geo-Conference \& EXPO-SGEM (2012).

Kereselidze, D., V. Trapaidze and G. Bregvadze: The methods for determination of hydrological specifications. Tbilisi: Universali (2009).

Khmaladze, G.: Water Resources of Gergia. Tbilisi: Metsniereba (2009).

Khomeriki, I. and M. Alaverdashvili: Water balance stady. Tbilisi: TSU (2003).

Nemykin, A.Y.: Landscape-basin approach to territorial land-utilization of Voronezh region. Voronezh: Thesis of Candidate of Geographic Sciences (2005).

Nikolaishvili, D.A.: Spatial-temporal analysis of georgia's landscapes. Tbilisi:TSU (2009)

Nikolaishvili D., D. Sartania, A. Ujmajuridze, L. Lagidze, V. Trapaidze and T. Nanobashvili: Samtskhe-Javakheti. Tbilisi, (2016)

State Water Cadastre, Perennial data about the regime and resources of land surface waters, vol. 6. Leningrad: Gidrometizdat (1987).

State water cadastre, principal hydrolgical properties. Leningrad: Gidrometizdat (1967).

State water cadastre, principal hydrological properties, Vol. 9., Leningrad: Gidrometizdat,. (1977).

State Water Cadastre, principal hydrological properties, Vol. 9. Leningrad: Gidrometizdat. (1978).

Svanidze, G.G. and V.S. Tsomaia: Water Resources of the Transcaucasus. Leningrad: Hydrometeoizdat. 264 p. (1988)

Tediashvili, A.: Research of phytomass as a landscape-geophysical parameter of natural-territorial complex and Its conditions. Tbilisi: TSU. (1984).

Trifonova, T.A., N.V. Mishchenko, N.V. Selivanova, S.M. Chesnokova and R.V. Repkin: Basin Approach in Ecological Researches. Vladimir. (2009).

Vladimirov, V. A., D.I. Shakarashvili and T.I. Gabrichidze: Water Balance of Georgia. Tbilisi: Metsniereba. (1974).

Winter, T.C.: The concept of hydrologic landscape. J. Amer. Water Reso. Assoc., 37,335-349(2001).

Wolock, D.M., T.C. Winter and G. McMahon: Delineation and evaluation of hydrologic-landscape regions in United States using geographic Information system tools and multyvariate statistical analysis. Environ. Manag., 34, 71-88. (2004). 